\title{
Comparison of the citation characteristics between the case reports/cases series versus the other study designs in the articles published in brazilian journals of ophthalmology
}

\author{
Comparação das características de citação entre os relatos de \\ caso/séries de casos versus demais desenhos de estudos nos \\ artigos publicados em periódicos brasileiros de Oftalmologia
}

Rodrigo Pessoa Cavalcanti Lira',2; Fernando Henrique Ramos Amorim; Fauze Abdulmassih Gonçalves; Carlos Eduardo Leite Arieta ${ }^{1}$; Newton Kara-Junior ${ }^{3}$

\begin{abstract}
Objective: To compare the citation characteristics of the case reports and the case series versus the other study designs of articles published, in 2008-2009, in Brazilian journals of ophthalmology indexed in Science Citation Index Expanded (SCIE). Methods: This study was a systematic review. Original articles were identified by review of documents published at the two Brazilians ophthalmology journals indexed at SCIE ("Arquivos Brasileiros de Oftalmologia" and "Revista Brasileira de Oftalmologia").All documents ("articles" and "reviews") listed at SCIE from January 1, 2008 to December 31, 2009 were included, except: "editorial materials"; "corrections"; "letters"; and "biographical items". The outcomes were the distributions, the number of citations (through the end of second year after publication date), the mean of the number of citations, and the likelihood of citation (cited at least once vs. no citation), according the study design of the article. Results: The search at the Web of Science revealed 382 articles. The distribution of articles according to study design was: Case Reports 106 articles (27.7\%) Case Series 50 (13.1\%), Sectional Studies 92 (24.1\%), Clinical Trials, Phase I or Phase II 40 (10.5\%), Clinical Trials, Phase III or Phase IV 29 (7.6\%), Non-Systematic Reviews 33 (8.6\%) and Experimental Studies $32(8.4 \%)$. The citation count was statistically lower $(\mathrm{P}<.001)$ in the Case Reports/Case Series $(0.55-\mathrm{SD}$ 1.05) compared with the others study designs (1.04 - SD 1.63). The likelihood citation was statistically lower $(\mathrm{P}<.001)$ in the Case Reports/Case Series (49/156 - 31.4\%) compared with the others study designs (110/226 - 48.7\%). Conclusion: Case reports and case series showed lower number of citations and likelihood citation than others study designs. The results of this study suggest that the editorial boards should publish only original or very rare Case Reports / Case Series with clinical significance or implications. This effort will bring benefits to the researcher, to the ophthalmologist who is looking for updating, and to the journal itself
\end{abstract}

Keywords: Ophthalmology; Journal impact factor; Journal article; Epidemiologic research design

\footnotetext{
${ }^{1}$ State University of Campinas, Campinas/SP, Brazil.

${ }^{2}$ Federal University of Pernambuco, Recife/PE, Brazil.

${ }^{3}$ São Paulo University, São Paulo/SP, Brazil.
}

Research Ethics Commission of the State University of Campinas: opinion 536/2012

The authors declare no conflicts of interest

Received for publication: 14/1/2013 - Accepted for publication: 20/10/2013 


\section{RESUMO}

Objetivo: Comparar as características de citação entre relatos de caso/séries de casos versus demais desenhos de estudos publicados nos periódicos brasileiros de oftalmologia indexados no Science Citation Index Expanded (SCIE). Métodos:Artigos originais foram identificados a partir da revisão dos documentos publicados nos "Arquivos Brasileiros de Oftalmologia" ou "Revista Brasileira de Oftalmologia". Todos os documentos listados no SCIE, de 01/01/2008 a 31/12/2009, foram incluídos, exceto: "editoriais"; "correções"; "cartas"; e "biografias". Os desfechos foram as distribuições, número de citações, média do número de citações e probabilidade de citação. Resultados: A pesquisa revelou 382 artigos. A distribuição dos artigos segundo desenho do estudo foi: relatos de caso 106, séries de casos 50, estudos transversais 92, ensaios clínicos fase I/fase II 40, ensaios clínicos fase III /fase IV 29, revisões não-sistemáticas 33 e estudos experimentais 32. A média do número de citações foi menor ( $<<0,001)$ entre relatos de caso/séries de casos $(0,55)$ quando comparados aos outros desenhos de estudos (1,04). A probabilidade de citação foi menor ( $p<0,001)$ entre relatos de caso/séries de casos (31,4\%) quando comparados aos outros desenhos de estudos (48,7\%).Conclusões: Os relatos de caso/séries de casos apresentaram média do número de citações e probabilidade de citação menores que os demais desenhos de estudo. Os resultados deste estudo sugerem que os conselhos editoriais devem publicar apenas relatos de caso/séries de casos originais ou muito raros que tenham repercussão clinica. Este esforço trará benefícios para o pesquisador, para o oftalmologista que estiver em busca de atualização e para a própria revista.

Descritores: Oftalmologia; Fator de impacto de revistas; Artigo de revista; Projetos de pesquisa epidemiológica

\section{INTRODUCTION}

$\mathbf{T}$ he relative merits of different study designs and their hierarchy are often discussed, but there are few data on the influence of study design on article citations. The relationship between the number of articles for each study design and their quality is almost inversely proportional (Figure 1) (1-3. $^{1.3}$.

Crosta et al. assessed the frequency of different study designs in articles published in Brazilian ophthalmology journals. They found that case reports and case series accounted for more than half of the articles ${ }^{4}$. However, they did not assess issues related to article citations.

The impact of study design on the frequency of citations in ophthalmology journals had not yet been investigated from a Brazilian perspective. In the present study, we focused on articles published between 2008 and 2009. Our main objective was to compare the citation characteristics of case reports and case series with other study designs in articles published in Brazilian

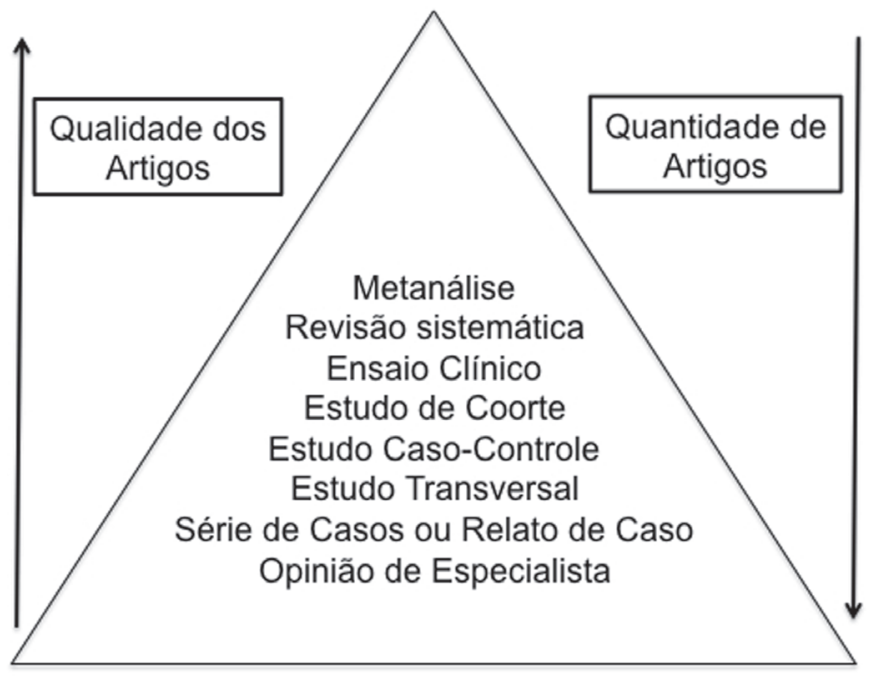

Figure 1. Article quality vs. quantity depending on study design ophthalmology journals indexed in the Science Citation Index Expanded (SCIE).

\section{Methods}

Original articles were identified among papers published in the two Brazilian ophthalmology journals indexed in SCIE: the Brazilian Archives of Ophthalmology (ABO) and the Brazilian Journal of Ophthalmology (RBO). All types of papers (articles and reviews) listed in SCIE between January 1, 2008 and December 31, 2009 were included, except editorials, corrections, letters, and biographical items.

The outcomes were the distribution, number of citations, citation measures (mean, standard deviation [SD], and range), and citation probability (cited at least once vs. no citation) for each study design until two years after the date of publication. Most articles are rarely cited in the year of publication, but the number of citations within two years is representative (it is the basis for estimating the impact factor of a journal).

In order to determine the citation frequency of articles included in our study, we used the Institute for Scientific Information (ISI) Web of Science database ${ }^{5}$. The search strategy in the Web of Science was: (publication name) Brazilian Archives of Ophthalmology OR Brazilian Journal of Ophthalmology; (year of publication) 2008-2009; (time) range of dates for articles published in 2008: from January 1, 2008 to December 31, 2010, and range of dates for articles published in 2009: from January 1, 2009 to December 31, 2011; and (citation database) Science Citation Index Expanded.

One group included case reports and case series, while the other included the remaining study designs. All items were carefully analysed to confirm the type of study design. Articles were grouped based on the classification used by the American Association of Ophthalmology and the American Journal of Ophthalmology $\mathrm{y}^{6,7}$.

Descriptive statistics were calculated. Continuous data were expressed as mean, standard deviation, and range. Differences between groups in continuous and categorical variables were compared using the Mann Whitney $\mathrm{U}$ test and the Pearson chi-square test, respectively. Statistical analysis was 
done using PSPP software. p-values were two-tailed. A significance level of 0.05 was adopted.

\section{ResUlts}

The search in the Web of Science found 382 articles. The distribution of articles, number of citations, citation measures (mean, standard deviation, and range), and citation probability for each study design are shown in Table 1.

The number of citations was significantly lower $(\mathrm{p}<0.001)$ for case reports/case series (mean, 0.55; SD, 1.05; range, 0-6) than for other study designs (mean, 1.04; SD, 1.63; range, 0-11).

Citation probability was significantly lower $(p<0.001)$ for case reports/ case series $(49 / 156,31.4 \%)$ than for other study designs $(110 / 226,48.7 \%)$.

\section{Discussion}

The results of this study showed that the number of citations and citation probability for case reports/case series are lower than other study designs.

These results stress the importance of study design in the citation of a study. The number of times an article is cited in a given period of time indicates the importance attributed to its findings by the scientific community. Journals specialised in publishing case reports and case series have a low impact factor ${ }^{8-}$ ${ }^{10}$. Impact factor is a measure of the visibility of a journal and is a method to rank journals by citation analysis, meaning that the more often the articles in a particular journal are cited, the higher its impact factor. However, citations does not guarantee respect and prestige to cited researchers, because studies can occasionally be cited in order to be negatively criticised. However, a citation means that the study is at least relevant to the scientific debate. Furthermore, it must be recognised that citation impact does not necessarily translate into clinical or scientific impact, although this is extremely difficult to measure ${ }^{1}$.

Evidence hierarchies rank papers according to study design in order to limit bias. Analysis of citations of medical articles has shown that studies high in the evidence hierarchy are most often cited. Furthermore, medical subspecialty and journal prestige can also influence the citation of an article ${ }^{1-3}$.
In this age of randomised clinical trials, molecular analysis of hereditary diseases, development of new medications, and large epidemiological studies, one can ask whether there is still room for case reports. The simple answer is that some of the best case reports/case series in ophthalmology have had an impact similar to papers with more complex study designs. Case reports can be useful for recognising and describing new diseases, detecting the side effects of drugs (both adverse and beneficial), studying disease mechanisms, and recognising rare disease manifestations; they are also a tool for medical education. For example, the observation that some patients with diabetes who had large chorioretinal scars did not develop proliferative retinopathy led to considering panphotocoagulation as a treatment. Recognising that macular holes could heal after spontaneous separation between the posterior vitreous and the retina led to considering vitrectomy as a treatment for macular holes.

The most important rule when it comes to writing a good case report or case series is to be very clear about the message the authors want convey ${ }^{11,12}$.

All types of research have their place. Researchers need to choose the best study design based on a simple strategy: the question to be answered is what determines the appropriate architecture and tactics of a study — not tradition, authority, expertise, paradigms, or schools of thought ${ }^{13}$.

Authors prefer study designs that provide a high level of scientific evidence. Original articles (including reviews) written with appropriate methodology are closer to scientific truth than case reports or case series, which in some cases may express an exception and not a rule.

From the point of view of a physician in daily practice who seeks to update their professional knowledge by reading a journal, a greater availability of original articles is advantageous, not only because articles present new information, but also because they are preceded by a brief review on what is already known about the subject.

Studies published in scientific journals have always been the main source used by professionals to update their medical knowledge; however, before the popularisation of the Internet, the major scientific journals were available only to subscribers or those with access to institutional libraries. Nowadays the Internet provides access at least to the abstract of any article published in major journals worldwide ${ }^{14,15}$.

From the viewpoint of editors, original articles are cited

Table 1

Distribution and characteristics of citations of articles published in the Brazilian Archives of Ophthalmology (ABO) and the Brazilian Journal of Ophthalmology (RBO) in 2008-2009

\begin{tabular}{|c|c|c|c|c|c|}
\hline \multirow[t]{2}{*}{ Study design } & \multirow{2}{*}{$\begin{array}{l}\text { Number of } \\
\text { articles (\%) }\end{array}$} & \multirow{2}{*}{$\begin{array}{l}\text { Number of } \\
\text { citation }(\%)\end{array}$} & \multicolumn{2}{|c|}{ Citation measures } & \multirow{2}{*}{$\begin{array}{c}\text { Citation } \\
\text { probability }(\%)\end{array}$} \\
\hline & & & Mean (SD) & Range & \\
\hline Case reports & $106(27.7)$ & $60(18.8)$ & $0.57(1.08)$ & $0-6$ & $34 / 106(19.7)$ \\
\hline Case series & $50(13.1)$ & $26(8.1)$ & $0.52(0.99)$ & $0-5$ & $15 / 50(30.0)$ \\
\hline Cross-sectional studies & $92(24.1)$ & $107(33.4)$ & $1.16(1.69)$ & $0-7$ & $44 / 92(47.8)$ \\
\hline Clinical trials (phase I or II) & $40(10.5)$ & $32(10.0)$ & $0.80(1.18)$ & $0-4$ & $18 / 40(45.0)$ \\
\hline Clinical trials (phase III or IV) & $29(7.6)$ & $28(8.8)$ & $0.97(0.98)$ & $0-3$ & $17 / 29(58.6)$ \\
\hline Non-systematic reviews & $33(8.6)$ & $35(10.9)$ & $1.06(1.87)$ & $0-10$ & $17 / 33(51.5)$ \\
\hline Experimental & $32(8.4)$ & $32(10.0)$ & $1.00(2.13)$ & $0-11$ & $14 / 32(43.7)$ \\
\hline Total & $382(100)$ & $320(100)$ & $0.84(1.44)$ & $0-11$ & $159 / 382(41.6)$ \\
\hline
\end{tabular}

*All document types (articles and reviews) except editorials. corrections. letters. and biographical items 
more frequently because they are more relevant and are more often red, thus playing a central role in the spread of knowledge. If these articles are the most important to the reader, then they should gain more space in scientific journals. A journal benefits from the number of citations an article generates in other journals $^{14-18}$. As a positive side effect, preferential publication of original articles will increase the impact factor of a journal, attracting the best authors and articles and thus creating a virtuous cycle.

The results of this study suggest that editorial boards should preferably publish original or very rare case reports/series that have clinical implications. This effort can help improve the impact of Brazilian ophthalmology journals and the quality of studies published in them, providing benefits to researchers, ophthalmologists who seek to update their knowledge, and the journals themselves.

\section{ReFERENCES}

1. Patsopoulos NA, Analatos AA, Ioannidis JP. Relative citation impact of variousstudy designs in the health sciences. JAMA. 2005;293(19):2362-6.

2. Cardwell JM. An overview of study design. J Small Anim Pract. 2008;49(5):217-8. Erratum in: J Small Anim Pract. 2008;49(9):487.

3. Giuffrida MA, Brown DC. Association between article citation rate and level ofevidence in the companion animal literature. J Vet Intern Med. 2012;26(2):252-8.

4. Crosta F, Nishiwaki-Dantas MC, Silvino W, Dantas PE. [Diversity and frequency of scientific research design and statistical methods in the "ArquivosBrasileiros de Oftalmologia": a systematic review of the "Arquivos Brasileiros deOftalmologia"-1993-2002]. Arq Bras Oftalmol. 2005;68(3):339-45. Review. Portuguese.

5. Thomson Reuters. Web of knowledge [v.5.7] - Web of science home [Internet].London:Thomson Reuters; 2013 [cited 2012 Ago 28]. Available from: http://apps.webofknowledge.com/WOS_General Search_input.do?highlighted_tab=WOS\&product=WOS\&last_prod= WOS\&SID=4DE1fee@PiabfLlcgJc\&search_mode=GeneralSearch

6. American Association of Ophthalmology. Ophthalmology - author info[Internet]. USA:American Association of Ophthalmology;2013c [citado 2012 Ago 28]. Available from: http://www.aaojournal.org/ authorinfo
7. American Journal of Ophthalmology. Author info - glossary of study designs [internet]. USA: American Association of Ophthalmology; 2013c [cited 2012 Ago 29]. Available from: http://www.ajo.com/ authorinfo\#glos

8. International Journal of Case Reports and Images. About: IJCRI. Journal - open access peer reviewed case reports [Internet]. [cited 2012 Dec 2]. Available from: http://www.ijcasereportsandimages.com/aboutus/about-ijcri-journal.php

9. BMJ Group. BMJ case reports - about [internet]. London: BMJ Publishing Group Ltd; 2013 [cited 2012 Dec 2]. Available from: http:// casereports.bmj.com/site/about/

10. Journal of Medical Case Reports. Instructions for authors [internet]. London: Journal of Medical Case Reports; 2013 [cited 2012 Dec 2]. Available from: http://www.jmedicalcasereports.com/authors/instructions

11. Levin LA, Bressler N. The case report. When small is beautiful. Arch Ophthalmol. 1996;114(11):1413.

12. Vandenbroucke JP. In defense of case reports and case series. Ann Intern Med. 2001;134(4):330-4.

13. Sackett DL, Wennberg JE. Choosing the best research design for each question. BMJ. 1997;315(7123):1636.

14. Portes AJ. A RBO na era da informação digital. Rev Bras Oftalmol. 2011;70(1):5-6.

15. Kara-Junior N. A democratização do conhecimento médico e seus desafios. Rev Bras Oftalmol. 2013;72(1):5-7.

16. Chamon W, Melo LA Jr. Impact factor and insertion of the ABO in the worldscientific literature. Arq Bras Oftalmol. 2011;74(4):241-2. English,Portuguese.

17. Rocha EM. [A great season for internationalization of Brazilian medicalresearch]. Arq Bras Oftalmol. 2011;74(6):391-2. English, Portuguese.

18. Kara-Junior N. A situação da pós-graduação strictu sensu no Brasil: instituição, docente e aluno. Rev Bras Oftalmol. 2012;71(1):577.

\section{Corresponding author:}

Rodrigo Pessoa Cavalcanti Lira

Rua Irmã Maria David, 200 apt.1302 - Casa Forte

CEP: 52061-070 - Recife, PE, Brazil

Tel.: +558199760274 - E-mail: rodrigopclira@hotmail.com 